\title{
PENGALAMAN PERAWAT SAAT TERKONFIRMASI COVID-19 DI RUMAH SAKIT DOKTER H. MOCHAMMAD ANSARI SALEH BANJARMASIN
}

\section{Iswanti, Bahrul Ilmi dan Muhammad Syafwani}

Universitas Muhammadiyah Banjarmasin dan Poltekkes Kemenkes Banjarmasin,

Kalimantan Selatan, Indonesia

Email: tia.iswanti@gmail.com, ilmie.bahrul@gmail.com dan

m.syafwanibjm@gmail.com

\section{Abstract}

The purpose of thestudy was to explore the experience of nurses who worked in the hospital doctor H. Mochammad Ansari Saleh Banjarmasin when confirmed COVID-19. Qualitative data was obtained through in-depth interviews on seven nurses at the hospital. This research uses qualitative research method with phenomenological approach, which aims to identify and explore nurse experience when confirmed COVID-19. There were seven respondents involved in the study. These seven respondents were nurses who treated COVID-19 confirmed patients who were still working in the COVID-19 room after being declared cured of COVID-19. The results found 6 main themes, namely: 1) COVID-19 transmission process; 2) Reasons for performing diagnostic checks; 3) Experiencing symptoms of COVID-19; 4) Experiencing symptoms of drug side effects; 5) Actions taken after COVID-19 is confirmed; and 6) Find information about COVID-19. When confirmed COVID-19 according to most participants is a not very overwhelming experience can be, but they still experience anxiety despite having prepared physically and mentally COVID-19 disease is experienced including in a mild degree, so the chance of recovery is very great. The experience of nurses when confirmed by COVID-19 according to most participants is not very overwhelming experience, but when confirmed COVID-19 they still experience anxiety even though they stated before it happened they were already preparing physically and mentally if at any time they were confirmed COVID-19.

Keywords: COVID-19; nurses; confirmed

\section{Abstrak}

Tujuan penelitian adalah untuk mengekplorasi pengalaman perawat yang bekerja di rumah sakit dokter H. Mochammad Ansari Saleh Banjarmasin saat terkonfirmasi COVID-19. Data kualitatif diperoleh melalui wawancara mendalam pada tujuh perawat di rumah sakit tersebut. Penelitian ini menggunakan metode penelitian kualitatif dengan pendekatan fenomenologi, yang bertujuan untuk mengidentifikasi dan mengeksplorasi pengalaman perawat saat terkonfirmasi COVID-19. Ada tujuh responden yang terlibat pada penelitian ini. Tujuh responden ini adalah perawat yang merawat pasien terkonfirmasi COVID-19 yang masih berkerja di ruangan COVID-19 setelah dinyatakan sembuh dari COVID-19. Hasil penelitian menemukan 6 tema utama yaitu: 1) Proses penularan COVID-19; 2) Alasan melakukan pemeriksaan diagnostik; 3) Mengalami gejala COVID-19; 4) 
Mengalami gejala efek samping obat; 5) Tindakan yang dilakukan setelah terkonfirmasi COVID-19; dan 6) Mencari informasi tentang COVID-19. Saat terkonfirmasi COVID-19 menurut sebagian besar partisipan adalah pengalaman yang tidak terlalu luar bisa, namun mereka tetap mengalami kecemasan meskipun sudah mempersiapkan fisik dan mental Penyakit COVID-19 dialami termasuk dalam derajat ringan, sehingga kesempatan untuk sembuh sangat besar. Pengalaman perawat saat terkonfirmasi COVID-19 menurut sebagian besar partisipan adalah pengalaman yang tidak terlalu luar bisa, namun saat terkonfirmasi COVID-19 mereka tetap mengalami kecemasan meskipun mereka menyatakan sebelum itu terjadi mereka sudah mempersiapkan fisik dan mental apabila suatu saat mereka terkonfirmasi COVID-19.

Kata kunci: COVID-19; perawat; terkonfirmasi

\section{Pendahuluan}

Akhir tahun 2019 dunia dikejutkan dengan munculnya penyakit baru mirip SARS yang dikenal dengan COVID-19. Virus penyebab penyakit ini ditularkan dari manusia ke manusia, orang yang memiliki gejala adalah sumber penyebaran COVID-19 yang paling sering. Namun orang yang tanpa gejala juga dapat menularkan karena penularan terjadi sebelum munculnya gejala, isolasi adalah cara terbaik untuk memutus mata rantai penyebarannya (Guo et al., 2020).

Informasi dari (Kompas.com, 2020) tanggal 24 Agustus 2020 kasus positif COVID-19 di dunia sebanyak 23,5 juta kasus dengan angka kematian lebih dari 800 ribu orang. Indonesia mencatat sebanyak 155.412 kasus dan telah memakan korban jiwa 6.759 orang (Badan Nasional Penanggulangan Bencana 2020) Sedangkan di Provinsi Kalimantan Selatan terdapat 7.838 orang terkonfirmasi positif, 335 orang meninggal dunia. Rumah sakit dokter H. Mochammad Ansari Saleh Banjarmasin hingga tanggal 12 September 2020 telah merawat pasien yang terkonfirmasi COVID19 sebanyak 542 orang, 139 orang di antaranya meninggal dunia.

Perawat merupakan salah satu tenaga kesehatan dengan jumlah besar di rumah sakit yang secara langsung terlibat dengan pasien selama 24 jam. Perawat memiliki risiko tinggi tertular COVID-19. Tingginya risiko tersebut menurut (Ehrlich, McKenney, \& Elkbuli, 2020) disebabkan oleh faktor lamanya berinteraksi dengan pasien dan jumlah pasien yang banyak menyebabkan meningkatnya jumlah virus di sekitar mereka, faktor tersebut diperparah dengan kelangkaan alat pelindung diri (APD) serta kurangnya pengetahuan terkait penggunaan APD.

Data dari (Damanik \& Gulo, 2020) per tanggal 23 Juni 2020 ada 129 orang perawat positif COVID-19 dan sudah 30 orang perawat meninggal dunia, sedangkan di Kalimantan Selatan sampai tanggal 22 Juli 2020 (Kompas, 2020) jumlah perawat yang terpapar COVID-19 sebanyak 164 orang. 1 orang perawat di kota Banjarmasin dinyatakan meninggal dunia pada tanggal 25 Juni 2020 (Kanal Kalimantan, 2020), rumah sakit dokter H. Mochammad Ansari saleh, hingga tanggal 12 September 2020 ada 30 orang perawat yang terkonfirmasi COVID-19, 1 orang di antaranya meninggal dunia. 
Apapun yang terjadi, pelayanan harus tetap berjalan. Jika perawat tidak bekerja, siapa lagi yang akan merawat pasien tersebut. Perawat yang sebelumnya pernah terkonfirmasi COVID-19 setelah dinyatakan sembuh diharuskan bekerja kembali untuk merawat pasien yang ada. Kemungkinan tertular kembali tentu saja ada, dan pastinya akan menimbulkan kecemasan bagi mereka. Seperti yang dinyatakan (Huang \& Zhao, 2020) dalam penelitiannya bahwa selain memberikan dampak fisik, COVID-19 juga dapat menyebabkan efek serius pada kesehatan mental seseorang.

Kondisi perawat yang pernah terkonfirmasi COVID-19 dan diikuti keharusan bekerja kembali setelah sembuh ini akan berpengaruh terhadap proses adaptasi mereka dalam merawat pasien COVID-19, karena setiap bertugas mereka berinteraksi dengan pasien. Seperti pernyataan (Wang et al., 2020) dalam penelitiannya bahwa rasa takut tertular COVID-19 menjadi pemicu masalah psikologis kecemasan, stigmatisasi dan depresi yang sangat merugikan bagi petugas kesehatan serta dapat memberikan efek buruk pada kualitas perawatan. Kecemasan harus mereka atasi supaya mereka dapat merawat pasien sesuai dengan proses asuhan keperawatan yang telah ditetapkan.

Proses adaptasi yang dilakukan para perawat tersebut sesuai dengan teori keperawatan yang dikemukakan oleh Sister Callista Roy, bahwa individu adalah mahluk biopsikososial sebagai satu kesatuan yang utuh. Seseorang dikatakan sehat jika mampu berfungsi untuk memenuhi kebutuhan biologis, psikologis dan sosial. Setiap orang selalu menggunakan koping, baik yang bersifat positif maupun negatif untuk dapat beradaptasi. Dalam hal ini perawat yang masih bekerja tersebut dikatakan memiliki koping yang adaptif karena mampu menjalankan fungsi dan perannya kembali sebagai seorang perawat.

Hasil studi pendahuluan yang dilakukan kepada 5 (lima) orang perawat di rumah sakit dokter H. Mochammad Ansari Saleh, 3 (tiga) orang mengatakan pernah terkonfirmasi COVID-19, saat mereka mengetahui hal tersebut mereka merasa sangat terpukul, mereka cemas akan menjadi parah, mereka juga takut akan menulari anggota keluarganya, terlebih lagi saat mereka memikirkan stigma dari teman dan masyarakat sekitar, 2 (orang) sampai menangis karena hal tersebut, satu orang lagi mengatakan hanya bisa terdiam saat mengetahui hasil pemeriksaan PCR yang positif.

Salah seorang dari mereka mengatakan kemungkinan tertular COVID-19 saat menjadi asisten dokter spesialis di luar rumah sakit, di tempat tersebut APD yang digunakan adalah APD level 2. yang lain mengatakan kemungkinan tertular saat bertugas di IGD, APD yang selalu digunakannya saat itu adalah APD level 3, sedangkan perawat yang terakhir tidak mengetahui pasti dari mana dia tertular virus tersebut, dia mengatakan kemungkinan tertular saat bertugas merawat pasien di ruang perawatan khusus COVID-19, saat bertugas perawat tersebut mengaku memakai APD level 3, namun ada saat di mana dirinya hanya memakai APD level 2 ketika kena giliran jaga di ners station. Menurutnya antara ruang perawatan dan ners station dibatasi dengan dinding kaca.

Ketiga perawat tersebut mengatakan setelah terkonfirmasi COVID-19, mereka diperintahkan untuk melakukan isolasi selama 2 (dua) minggu di tempat isolasi yang disediakan pemerintah karena gejala yang mereka alami ringan saja. Ditempat isolasi 
tersebut mereka diminta untuk istirahat, diberi makanan yang bergizi dan vitamin. Setelah dinyatakan sembuh mereka bekerja kembali untuk merawat pasien karena sudah menjadi kewajiban mereka sebagai perawat.

Perasaan takut tertular kembali COVID-19 sangat besar, namun mereka mengatasinya dengan mencari tahu lagi tentang COVID-19 melalui internet, lebih teliti lagi saat menggunakan APD, serta sering mencuci tangan dan menjaga jarak fisik (physical distancing) dengan orang lain.

Perawat yang lain mengatakan belum pernah terkonfirmasi COVID-19, salah seorang dari mereka mengatakan pernah mengalami gejala mirip COVID-19 namun setelah dilakukan pemeriksaan swab hasilnya negatif, sedangkan 1 (satu) orang sisanya belum pernah mengalami gejala yang sama dan belum pernah diperiksa. Dua orang perawat ini mengatakan mereka merawat pasien di rumah sakit karena ditugaskan, jika menolak, maka harus rela berhenti bekerja karena dianggap tidak dapat melaksanakan tugas sesuai peraturan yang berlaku. Selama merawat pasien mereka menggunakan APD sesuai standar, mereka mencuci tangan sesering mungkin dan kadang-kadang menggunakan hand sanitizer. Kelimanya mengaku sangat khawatir akan menjadi agen penyebar COVID-19 ke keluarga mereka, mereka hanya berdoa dan berharap agar mereka dan orang di sekitarnya tidak tertular COVID-19.

Berdasarkan fenomena tersebut, maka dirasa penting untuk melakukan studi yang menggali lebih dalam tentang pengalaman perawat saat terkonfirmasi COVID-19 di rumah sakit dokter H. Mochammad Ansari Saleh Banjarmasin.

\section{Metode Penelitian}

Penelitian ini menggunakan metode penelitian kualitatif dengan pendekatan fenomenologi, yang bertujuan untuk mengidentifikasi dan mengeksplorasi pengalaman perawat saat terkonfirmasi COVID-19. Ada tujuh responden yang terlibat pada penelitian ini. Tujuh responden ini adalah perawat yang merawat pasien terkonfirmasi COVID-19 yang masih berkerja di ruangan COVID-19 setelah dinyatakan sembuh dari COVID-19.

\section{Hasil dan Pembahasan}

Karakteristik partisipan (responden) meliputi pendidikan partisipan dari diploma 3 (D3) sampai Sarjana Keperawatan (S1), 6 orang berjenis kelamin laki-laki dan 1 orang partisipan perempuan dengan rentang usia 28 - 40 tahun. Sebanyak 4 orang partisipan berstatus PNS dan 3 orang lainnya karyawan BLUD. Semua partisipan telah menikah.

Hasil penelitian mengidentifikasi pengalaman perawat saat terkonfirmasi COVID19 sebanyak 6 (enam) tema sebagai berikut:

1. Proses penularan COVID-19

1) Kontak langsung

Hasil penelitian ini mengungkapkan bahwa partisipan tertular COVID-19 melalui kontak langsung karena tinggal serumah dengan anggota keluarga yang terkonfirmasi COVID-19 dan bersentuhan dengan mereka. 
Penularan SARS-CoV-2 dapat terjadi melalui kontak langsung dengan droplet yang keluar saat orang yang terinfeksi. Penyebaran COVID-19 antar anggota keluarga merupakan salah satu penyebab penyebaran dapat menjadi lebih luas di masyarakat. Guo et al. (2020) dalam penelitiannya menyebutkan bahwa penularan SARS-CoV-2 dari manusia ke manusia terjadi terutama antara anggota keluarga, termasuk kerabat dan teman-teman yang berhubungan dekat dengan pasien atau pembawa inkubasi.

Bersentuhan dengan orang yang terinfeksi melalui tangan juga dapat memindahkan SARS-CoV-2 penyebab COVID-19 dari satu orang ke orang lainnya. Hal itu sesuai dengan hasil penelitian Jayaweera et al. (2020) bahwa bersentuhan fisik secara langsung antara individu yang terinfeksi dengan orang yang rentan dapat menyebabkan penularan virus.

2) Melalui Udara

Ada juga partisipan yang tertular COVID-19 melalui transmisi udara karena melakukan intubasi pada pasien yang dirawatnya. Penularan lewat udara terjadi ketika seseorang menghirup virus yang dibawa oleh partikel yang melayang di udara. Penelitian (Guo et al., 2020) menyebutkan bahwa SARSCoV-2 didistribusikan di udara dan permukaan objek di ICU dan ruang rawat inap pasien COVID-19 yang berarti berpotensi tinggi menular kepada petugas kesehatan atau orang lain yang kontak dekat dengan pasien, oleh karena itu tindakan perlindungan yang lebih ketat harus dilakukan oleh petugas yang bekerja di ruang ICU.

Apabila ditinjau dari teori adaptasi Roy, maka penularan COVID-19 melalui kontak langsung atau melalui udara menjadi stimulus fokal bagi partisipan. Kondisi tersebut menjadi sebab partisipan harus melakukan adaptasi untuk menghadapi kondisinya yang menderita COVID-19.

2. Alasan melakukan pemeriksaan COVID-19

1) Pemeriksaan Rapid

Partisipan menyatakan alasan mereka melakukan pemeriksaan rapid karena pernah kontak dengan orang terkonfirmasi COVID-19, mengalami gejala mirip COVID-19 serta pernah kontak dengan orang rapid reaktif.

Pemeriksaan rapid sering dilakukan karena hasilnya lebih cepat dan biayanya murah sehingga dapat dijadikan screening awal pemeriksaan COVID19 meskipun hasil pemeriksaan ini tidak bisa digunakan untuk penegakan diagnosa. Pemeriksaan ini dilakukan pada orang yang pernah kontak erat dengan orang terkonfirmasi COVID-19, mengalami gejala mirip COVID-19, atau pernah kontak dengan orang rapid reaktif. Hal ini sejalan dengan penelitian yang dilakukan (Santosa, 2020) yang menyebutkan bahwa di Indonesia tes rapid antibodi dan/ atau antigen dapat digunakan pada orang tanpa gejala (OTG) atau kasus kontak dari pasien terkonfirmasi COVID-19. 
2) Pemeriksaan swab (PCR)

Partisipan menyatakan melakukan pemeriksaan swab karena pernah kontak dengan orang terkonfirmasi COVID-19, mengalami gejala mirip COVID-19, pernah merawat pasien terkonfirmasi COVID-19 serta hasil rapid yang reaktif.

Pemeriksaan swab dilakukan untuk menegakkan diagnosa COVID-19. Bagi orang yang pernah kontak dengan orang terkonfirmasi COVID-19, mengalami gejala mirip COVID-19, pernah merawat pasien terkonfirmasi COVID-19 atau hasil rapidnya reaktif diwajibkan untuk melakukan pemeriksaan ini. (Hadaya, Schumm, \& Livingston, 2020) menyebutkan bahwa pemeriksaan PCR dilakukan untuk individu yang akan mengubah pengobatan dan untuk orang yang memiliki risiko tinggi untuk hasil yang buruk akibat COVID-19. Prado et al. (2020) juga menyebutkan bahwa seseorang yang memiliki gejala mirip COVID-19 perlu dilakukan pemeriksaan swab (PCR) untuk memastikan apakah orang tersebut terinfeksi COVID-19 atau tidak meskipun hasil rapidnya nonreaktif.

3) Pemeriksaan radiologi

Hasil penelitian ini menunjukkan bahwa terdapat partisipan yang melakukan pemeriksaan radiologi untuk memastikan adanya pneumonia. Gambaran paru menjadi salah satu acuan untuk mengetahui infeksi COVID-19 yang sedang terjadi. Peradangan yang terjadi di paru-paru menyebabkannya membengkak hingga terisi cairan. Gambaran paru ini akan terlihat melalui pemeriksaan rontgen thorax. Penelitian (Wong et al., 2020) menyebutkan bahwa gambaran paling umum dari pemeriksaan rontgen toraks pasien COVID-19 adalah konsolidasi sebanyak 59\% dan ground glass opacity (GGO) sebanyak 41\%, dengan distribusi perifer atau posterior, terutama pada lobus bawah. Sejalan dengan itu, (Durrani, Inam ul Haq, \& Yousaf, 2020) juga menyatakan bahwa pasien COVID-19 yang masuk kategori ringan hingga sedang memiliki gambaran paru-paru yang terlihat buram.

3. Mengalami Gejala COVID-19

1) Fisik

Partisipan menyatakan selama terkonfirmasi COVID-19 ada yang tidak mengalami gejala apapun dan ada yang mengalami gejala fisik ringan. Orang yang terkonfirmasi COVID-19 kadang-kadang tidak mengalami gejala karena daya tahan tubuh penderitanya lebih kuat sehingga tidak menimbulkan gejala. Hasil penelitian (Ooi \& Low, 2020) menunjukkan bahwa setengah dari 634 penumpang kapal Diamond Princess yang positif SARS-CoV-2 tidak menunjukkan gejala.

Gejala fisik COVID-19 dapat berupa demam, batuk kering, dispnea, fatigue, nyeri otot, sakit kepala, gambaran opasifikasi ground-glass pada foto toraks. Penelitian (Wu et al., 2020) menyebutkan bahwa 98\% pasien dalam studi mereka mengalami demam, $78 \%$ memiliki suhu lebih dari $38^{\circ} \mathrm{C}, 76 \%$ pasien batuk, $44 \%$ mengalami kelelahan dan nyeri otot, dan 55\% dari pasien mengalami dyspnea. Sejumlah kecil pasien juga mengalami ekspektorasi (28\%), sakit kepala $(8 \%)$, hemoptisis $(5 \%)$, dan diare (3\%). Hasil penelitian (Lee, Min, Lee, \& Kim, 
2020) juga menunjukkan anosmia dan ageusia banyak ditemukan pada pasien asimtomatik atau dengan gejala minimal, usia muda, dan berjenis kelamin perempuan.

2) Konsep diri

Partisipan penelitian menyatakan selama terkonfirmasi COVID19 mengalami masalah pada konsep dirinya. Konsep diri merupakan cara pandang individu terhadap diri sendiri, baik yang bersifat fisik, sosial maupun psikologis, yang didapat dari hasil interaksi dengan orang lain serta pengalaman yang dilalui selama hidupnya. Konsep diri menurut (Stuart, Keliat, \& Pasaribu, 2016) terdiri dari identitas diri, gambaran diri/citra tubuh, harga diri, ideal diri dan peran.

Hasil penelitian ini mengungkapkan bahwa saat terkonfirmasi partisipan mengidentifikasi dirinya sebagai pasien yang harus bergantung kepada keluarga untuk memenuhi kebutuhan mereka Partisipan yang merasa bahwa dirinya adalah seorang pasien berarti memiliki identitas diri yang positif, karena dengan begitu dirinya menyadari kondisinya dan berusaha untuk mencari pengobatan. Kondisi tergantungnya mereka pada keluarga untuk memenuhi kebutuhannya sesuai dengan hasil penelitian (Fan et al., 2020) yang menyatakan bahwa sebagian besar pasien yang mandiri sebelum sakit, setelah diisolasi tidak dapat lagi melakukan rutinitas seperti biasa sehingga menimbulkan rasa frustrasi dalam diri mereka.

Saat dinyatakan terkonfirmasi COVID-19 partisipan penelitian ini juga menggambarkan bahwa dirinya sekarang sedang sakit meskipun gejala yang dialami ringan atau bahkan tidak ada. Perasaan tersebut turut mendorong mereka mencari pengobatan dan melakukan tindakan untuk mencegah penularan kepada anggota keluarganya yang lain. (Al Noman et al., 2020) menyebutkan bahwa individu yang merasa dirinya memiliki masalah kesehatan atau merasa sakit akan melakukan tindakan apapun untuk mencari pengobatan yang tepat. Selain itu, mereka mengalami kecemasan karena takut menularkan kepada anggota keluarga yang lain dan harus melakukan isolasi mandiri sehingga tidak bisa melakukan kegiatan di masyarakat. Hal ini sesuai dengan hasil penelitian (Brooks et al., 2020) yang menunjukkan bahwa partisipan penelitiannya melaporkan perasaan takut tentang kesehatan mereka sendiri dan takut menulari orang lain terutama anggota keluarga mereka selama masa karantina.

Konsep harga diri saat terkonfirmasi COVID-19 mereka ungkapkan sebagai perasaan sedih karena dikucilkan dari masyarakat. Partisipan juga merasa malu jika masyarakat sekitar mengetahui bahwa dirinya terkonfirmasi COVID-19. Mereka takut jika masyarakat tahu, maka tidak akan mau lagi berobat ke balai pengobatan miliknya.

COVID-19 yang menular menyebabkan masyarakat menjadi takut dan waspada secara berlebihan sehingga mereka menjauhi dan mengucilkan para penderitanya. Hal itu menyebabkan orang terkonfirmasi menyembunyikan penyakit-nya. Hasil penelitian (Dwinantoaji \& Sumarni, 2020) menyebutkan 
bahwa sikap masyarakat yang mengucilkan dapat menyebabkan banyak penderita COVID-19 merasa malu jika harus mengakui bahwa mereka terkonfirmasi COVID-19, mereka juga takut akan menyebabkan penderitaan bagi keluarga yang lain karena dijauhi oleh orang di sekitarnya yang khawatir akan tertular.

Partisipan dalam penelitian ini menyatakan ideal dirinya melalui harapan agar dapat segera sembuh dari COVID-19 dengan hasil swab yang negatif. Hasil swab evaluasi yang negatif merupakan indikator bahwa seorang yang terkonfirmasi dinyatakan sembuh dari penyakit tersebut.

Kondisi partisipan yang mengalami COVID-19 dengan gejala ringan memberikan kesempatan besar bagi mereka untuk sembuh, sehingga harapan yang ada tidaklah terlalu berlebihan. Individu yang memiliki ideal diri yang disesuaikan dengan kemampuannya akan menjadikan pengharapan atau citacitanya tersebut lebih mudah untuk diraih dan akan memberikan kesempatan lebih besar untuk tercapai. Namun jika ideal dirinya terlalu tinggi, maka dapat menyebabkan peluang memperoleh kekecewaan yang besar karena gagal. Hal tersebut didukung oleh (Saputri \& Moordiningsih, 2016) dalam penelitiannya yang menyebutkan bahwa gambaran seseorang tentang cita-cita dirinya jika tidak sesuai dengan kenyataan maka akan menyebabkan kesenjangan, semakin besar kesenjangan yang terjadi maka semakin besar pula rasa tidak nyaman yang ditimbulkan.

Komponen konsep diri yang terakhir adalah peran. Hasil penelitian ini menunjukkan bahwa partisipan mengaku selama menderita COVID-19 tidak dapat melaksanakan peran mereka di keluarga dan masyarakat karena harus melakukan isolasi mandiri untuk mencegah penularan COVID-19. Hasil penelitian (Sepúlveda-Loyola et al., 2020) juga mengamati bahwa aktivitas fisik pada saat isolasi sangat menurun di semua populasi, terutama aktivitas berat dan waktu berjalan. Semakin ketat seseorang melakukan protokol isolasi mandiri maka semakin dia tidak dapat melaksanakan perannya di keluarga dan masyarakat.

3) Interdependensi

Selama terkonfirmasi COVID-19, partisipan dalam penelitian ini mengaku tidak bisa lagi bekerja merawat pasien COVID-19. Isolasi mandiri menyebabkan orang tidak bisa pergi ke tempat kerja untuk menghindari penularan. Hal ini menyebabkan fungsi interdependensi perawat sebagai anggota tim yang merawat pasien COVID-19 tidak dapat dilaksanakan. (Brooks et al., 2020) dalam penelitiannya menyatakan bahwa kerugian finansial dapat menjadi masalah selama karantina karena banyak orang tidak dapat bekerja dan aktivitas profesional terganggu tanpa perencanaan yang matang. Hasil penelitian (Barnes \& Sax, 2020) juga menyebutkan bahwa salah satu cara untuk mencegah penularan COVID-19 adalah tidak datang ke tempat kerja atau tempat umum saat seseorang merasa tidak enak badan. 
Menurut teori adaptasi Roy, kondisi partisipan yang mengalami gejala COVID-19 merupakan efektor yang terjadi setelah individu melakukan mekanisme kontrol sistem regulator dan kognator.

4. Mengalami gejala efek samping obat

Partisipan dalam penelitian ini mengungkapkan bahwa setelah mereka minum obat oseltamivir mengalami perasaan gelisah, ingin selalu beraktivitas tetapi badan terasa lemas dan letih. Mereka juga mengalami mual dan perutnya terasa seperti diremas-remas. Sesuai dengan hasil penelitian (Antipov \& Pokryshevskaya, 2019) efek samping oseltamivir diantaranya berupa rash, dermatitis, mual, muntah, sakit kepala, dan gangguan neuropsikiatri seperti halusinasi. Sejalan dengan hal tersebut, FDA juga menginformasi bahwa oseltamivir memiliki efek samping mual, muntah, nyeri perut, insomnia, vertigo, diare, pusing, sakit kepala, lemas, pendarahan pada lambung, tingkah laku abnormal.

Kondisi partisipan yang mengalami gejala efek samping obat saat terkonfirmasi COVID-19 menurut teori Roy juga merupakan efektor yang dipicu oleh adanya mekanisme kontrol sistem regulator dan sistem kognator.

5. Tindakan yang dilakukan setelah terkonfirmasi COVID-19

1) Mencegah penularan

Hasil penelitian ini menunjukkan bahwa partisipan melakukan isolasi mandiri, rawat inap di rumah sakit, serta mencegah kontak dengan anggota keluarga dan tetangga untuk menghindari penularan COVID-19.

Isolasi mandiri dilakukan untuk mencegah penularan COVID-19 kepada orang di sekitar penderita. Orang yang melakukan isolasi mandiri wajib menggunakan kamar terpisah, memakai masker dan harus menjaga jarak lebih dari 1 (satu) meter dari anggota keluarga lainnya, menghindari pemakaian bersama peralatan makan, peralatan mandi dan linen. (Mangalla, Simatupang, Samhuddin, Kadir, \& Kadir, 2020) dalam penelitiannya menyebutkan jika seseorang terkonfirmasi COVID-19 maka salah satu tindakan yang harus dilakukan adalah mengisolasi diri dari keluarga atau orang lain.

Partisipan penelitian ini juga ada yang dirawat di rumah sakit karena merasa gejala yang dialaminya sudah tidak tertahankan, sehingga dia memutuskan untuk dirawat di rumah sakit agar mendapatkan penanganan yang maksimal.

Pasien COVID-19 yang mengalami gejala lebih parah dianjurkan untuk dilakukan perawatan di rumah sakit agar dapat dipantau secara intensif, termasuk pemberian terapi suportif dan terapi lainnya.

Penularan COVID-19 juga dapat dihindari dengan cara mencegah kontak dengan anggota keluarga dan tetangga selama terkonfirmasi COVID-19. Selama melakukan isolasi mandiri, acara berkumpul dengan tetangga dianjurkan untuk dihindari. Apabila terpaksa harus mendatangi seseorang atau pergi ke luar, protokol kesehatan harus dijalankan.

2) Melakukan pengobatan

Seluruh partisipan dalam penelitian ini melakukan pengobatan sebagai upaya untuk mempercepat proses penyembuhan COVID-19. Jenis pengobatan 
yang mereka lakukan yaitu pemberian obat simtomatik, antivirus, vitamin, berkumur-kumur dengan obat kumur antiseptik dan mencuci hidung dengan cairan garam fisiologis.

Pengobatan simtomatik yang dilakukan partisipan diantaranya dengan pemberian parasetamol dan antrain untuk demam, pemberian obat flu, simvastatin untuk menurunkan kadar kolesterol dalam darah, ranitidine untuk mual dan acetylcysteine untuk mengurangi batuk. Sedangkan obat antivirus yang digunakan partisipan di antaranya adalah oseltamivir, azithromycin, alluvia dan hyloquin (hydroxychloroquine) yang diperoleh berdasarkan saran dari dokter. Pengobatan tersebut sesuai dengan pedoman yang dikeluarkan oleh (Perhimpunan Dokter paru Indonesia, 2020) bahwa penderita COVID-19 derajat ringan dapat diberikan pengobatan simtomatik dan pengobatan antivirus sesuai tatalaksana yang sudah ditetapkan (Hafeez, Ahmad, Siddqui, Ahmad, \& Mishra, 2020) dalam penelitiannya merekomendasikan pengobatan simtomatik untuk pasien COVID-19 yang mengalami demam tinggi melebihi $38,5^{\circ} \mathrm{C}$ dapat diberikan obat antipiretik ibuprofen secara oral, 5-10 $\mathrm{mg} / \mathrm{kgBB}$ setiap kali pemberian; acetaminophen secara oral, $10-15 \mathrm{mg} / \mathrm{kgBB}$ setiap kali pemberian. (Harapan et al., 2020) juga menyebutkan bahwa meskipun belum ada bukti kuat tentang efektifitas antivirus yang dipakai untuk pengobatan SARS dan MERS pada pasien COVID-19, namun obat antivirus seperti oseltamivir yang dikombinasikan dengan pengobatan antibiotik empiris telah digunakan untuk mengobati pasien COVID-19.

Terapi potensial lain yang digunakan untuk tata laksana kasus COVID-19 adalah pemberian vitamin $\mathrm{C}$ untuk meningkatkan sistem imun dan sebagai antioksidan. Hasil penelitian (Carr \& Maggini, 2017) menyebutkan bahwa vitamin $\mathrm{C}$ dapat meningkatkan kemotaksis dan fagositosis neutrofil sehingga meningkatkan bersihan mikroba. Selain itu, (Van Gorkom et al., 2018) juga menemukan bahwa vitamin $\mathrm{C}$ dapat meningkatkan diferensiasi, proliferasi, dan memodulasi fungsi sel T, Sel B, dan sel natural killer serta mampu menginduksi produksi antibodi pada manusia.

Pengobatan yang dilakukan partisipan berikutnya adalah berkumur dengan menggunakan antiseptik yang mengandung povidone-iodine 1 persen. Tindakan ini dianggap ampuh melawan kuman yang ada di mulut. Hal tersebut sesuai dengan hasil penelitian (Anderson et al., 2020) tentang studi in vitro PVP-I 1,0\% dengan uji viral kill time terhadap sel Vero-E6 yang merupakan kultur virus COVID-19 dengan angka viral kill time yang mencapai $99.99 \%$ yang menunjukkan aktivitas virucidal terhadap COVID-19 dalam waktu 30 detik.

Selanjutnya, mencuci hidung menjadi pengobatan terakhir yang dipilih partisipan untuk mengatasi COVID-19. Tindakan pencucian hidung dengan menggunakan larutan garam fisiologis akan sangat dapat bermanfaat untuk mengencerkan lendir yang kental, mengurangi gejala alergi, mencegah terkumpulnya bakteri dan mengurangi radang. Hal tersebut sesuai dengan penelitian (Casale, Rinaldi, Sabatino, Moffa, \& Ciccozzi, 2020) yang 
menyebutkan bahwa mukosa hidung merupakan area yang rentan bagi COVID19 untuk berkoloni karena pembuluh darahnya yang melimpah serta kelenjar musinous dan kelenjar serosa yang menciptakan lingkungan yang lembab

3) Meningkatkan daya tahan tubuh

Partisipan dalam penelitian ini menyatakan bahwa mereka meningkatkan daya tahan tubuh dengan cara makan makanan yang bergizi, mengonsumsi madu, mengonsumsi minuman herbal, berolahraga, berjemur di bawah sinar matahari dan berpikir positif.

Mengonsumsi makanan yang mengandung antioksidan seperti sayur dan buah dapat membantu tubuh melawan radikal bebas. Untuk menjaga imunitas tubuh, diperlukan juga asupan nutrisi yang cukup. Hal itu sejalan dengan hasil penelitian (Iddir et al., 2020) bahwa makanan adalah faktor kunci dari sistem kekebalan tubuh yang kuat dan mengurangi risiko terkena infeksi. Menurut (Dalimartha \& Adrian, 2013) buah dan sayur merupakan sumber antioksidan, vitamin, dan mineral.

Hasil penelitian ini juga mengungkapkan fakta bahwa selama sakit ada partisipan yang mengonsumsi madu untuk meningkatkan daya tahan tubuhnya. Menurut (Samarghandian, Farkhondeh, \& Samini, 2017) madu mengandung nutrisi yang meliputi karbohidrat, vitamin C, vitamin B, asam amino, magnesium, phosphor, dan kalium.

Tanaman herbal lainnya yang digunakan partisipan adalah jahe merah yang memiliki kandungan senyawa aktif yang lebih tinggi dibandingkan varietas jahe lainnya. Menurut (Indonesia \& Indonesia, 2012) jahe merah memiliki aktivitas sebagai immunomodulator untuk meningkatkan daya tahan tubuh manusia. Hasil penelitian (Febriani, Riasari, Winingsih, Aulifa, \& Permatasari, 2018) juga menyebutkan bahwa jahe merah mengandung flavonoid, tanin, polifenolat, monoterpen \& seskuiterpen, triterpenoid \& steroid, kuinon dan saponin.

Berolahraga menjadi salah satu pilihan cara yang dilakukan partisipan untuk meningkatkan daya tahan tubuhnya. Orang yang terkonfirmasi COVID-19 dengan gejala ringan tetap bisa berolah raga untuk meningkatkan daya tahan tubuh. Hal ini didukung oleh hasil penelitian (Shirvani, 2020) yang menyebutkan bahwa orang dengan gejala ringan gangguan saluran pernapasan bagian atas dapat melakukan latihan ringan, peregangan, keseimbangan, aerobik, dan latihan mental. Individu yang dicurigai mengalami gejala COVID-19 seperti demam, sakit tenggorokan parah, nyeri tubuh, sesak napas, kelelahan umum, batuk dada, dan saturasi oksigen $93 \%$ saat istirahat harus menghindari melakukan olahraga.

Berikutnya, berjemur di bawah sinar matahari dilakukan partisipan untuk meningkatkan produksi vitamin D yang berfungsi untuk meningkatkan kekebalan tubuh dalam melawan COVID-19. Hal ini sesuai dengan hasil penelitian (Miyauchi \& Nakajima, 2016) yang memperlihatkan fakta bahwa berjemur dengan hanya wajah dan kedua punggung tangan saja yang terkena sinar matahari selama 6-7 menit, maka tubuh akan menghasilkan $10 \mu \mathrm{g}$ vitamin 
D atau setara dengan 400 IU, jumlah vitamin D standar yang dibutuhkan oleh tubuh per hari.

Terakhir, berpikir positif dijadikan pilihan tindakan yang dilakukan partisipan untuk meningkatkan imunitas tubuh. Dengan daya tahan tubuh yang tetap terjaga baik, maka tubuh tidak mudah terkena penyakit. Dan bagi yang sudah terkonfirmasi COVID-19, tentunya hal tersebut akan membantu dalam proses penyembuhan penyakit. Penelitian (Morey, Boggero, Scott, \& Segerstrom, 2015) menyebutkan tentang efek stres yang dapat meningkatkan kemungkinan berkembang-nya penyakit serta memperburuk kondisi yang sudah ada sebelumnya.

Jika ditinjau dari teori adaptasi Roy, tindakan yang dilakukan partisipan setelah terkonfirmasi COVID-19 merupakan respon adaptasi yang adaptif sehingga diharapkan menghasilkan output yang dapat menyebabkan kesembuhan pada diri partisipan.

\section{Mencari informasi tentang COVID-1}

1) Media

Hasil penelitian ini menunjukkan bahwa partisipan berusaha mencari informasi tentang COVID-19 melalui internet, televisi dan buku.

Internet digunakan setiap orang untuk mendapatkan informasi dari seluruh dunia tentang COVID-19 karena mudah diakses. (Siste et al., 2020) dalam penelitiannya menunjukkan bahwa salah satu faktor prediktif yang menyebabkan perilaku adiksi internet di masa pandemi adalah dorongan untuk mencari informasi terkait penyakit COVID-19. Stres psikologi yang timbul akibat rasa takut terhadap infeksi virus COVID-19 juga dapat mendasari seseorang untuk mencari rekreasi melalui aktivitas online atau internet sebagai salah satu bentuk adaptasi.

Sementara itu, penggunaan televisi selama masa pendemi mengalami peningkatan yang signifikan. Hasil survey Nielsen TAM (2020) di 11 kota menunjukkan rata-rata kepemirsaan televisi mulai meningkat 12 persen pada tanggal 11 Maret menjadi 13,8 persen pada 18 Maret atau setara dengan penambahan sekitar 1 juta pemirsa televisi. Banyaknya pemberitaan di beberapa stasiun televisi tentang COVID-19 sejak 1-18 Maret menyebabkan kenaikan kepemirsaan program berita secara signifikan (25\%), buku juga merupakan sumber informasi yang dapat membuka wawasan tentang berbagai hal termasuk informasi tentang COVID-19. Walaupun buku yang membahas tentang COVID19 saat ini masih sangat terbatas, namun sudah ada beberapa referensi yang dikeluarkan Kementerian Kesehatan RI yang dapat dijadikan sumber informasi. Sejalan dengan itu, (Riyan, Prijana, \& Sukaesih, 2015) menyatakan bahwa membaca buku merupakan suatu cara untuk mendapatkan informasi. Semakin banyak membaca, semakin banyak pula informasi yang didapatkan. 
Analisis Kandungan Merkuri (Hg) dan Hidrokuinon pada Sediaaan Krim Pemutih

2) Pengalaman pribadi

Partisipan lainnya juga mengatakan bahwa mereka mencari informasi tentang COVID-19 melalui pengalaman pribadi mereka yang langsung merawat pasien COVID-19, dari pelajaran di sekolah dan berbagi informasi (sharing) dengan teman sejawat.

Pengalaman pribadi dapat digunakan untuk mendapatkan pengetahuan atau informasi dengan cara mengulang kembali pengalaman yang diperoleh dalam memecahkan masalah yang dihadapi pada masa yang lalu. Jika pada satu masalah orang menemukan cara pemecahannya maka pada masa lain saat seseorang menemukan masalah yang sama, dia akan melakukan cara yang sama untuk memecahkannya. (Pusparini, 2020) dalam penelitiannya juga menyebutkan bahwa semakin banyak pengalaman seseorang maka akan semakin meningkat pula juga menyatakan bahwa pengetahuan dipengaruhi oleh dua faktor, yaitu pendidikan formal dan pendidikan non formal. Semakin tinggi pendidikan dan pengalaman seseorang maka semakin luas pula pengetahuannya. (Dwiyanti, 2017) juga menyebutkan bahwa kegiatan berbagi pengetahuan (sharing) adalah sebagai bentuk berbagi dan mencari ilmu melalui tanya jawab.

Menurut teori adaptasi Roy, usaha partisipan untuk mencari informasi tentang COVID-19 merupakan mekanisme kontrol sistem kognator yang akan dapat membantu partisipan dalam menyesuaikan diri dengan perubahan yang terjadi pada dirinya.

\section{Kesimpulan}

Pengalaman perawat saat terkonfirmasi COVID-19 menurut sebagian besar partisipan adalah pengalaman yang tidak terlalu luar bisa, namun saat terkonfirmasi COVID-19 mereka tetap mengalami kecemasan meskipun mereka menyatakan sebelum itu terjadi mereka sudah mempersiapkan fisik dan mental apabila suatu saat mereka terkonfirmasi COVID-19. Penyakit COVID-19 yang mereka alami termasuk dalam derajat ringan, sehingga kesempatan untuk sembuh sangat besar. Selain itu, pengetahuan tentang COVID-19 yang banyak dapat membantu mereka dalam beradaptasi dengan masalah yang muncul. Dari seluruh perawat yang menjadi partisipan, ada satu orang yang menganggap kejadian ini luar biasa karena perawat tersebut mengalami gejala COVID-19 yang menurutnya lumayan parah, perawat tersebut sempat dirawat di rumah sakit karena gejala yang dideritanya 


\section{BIBLIOGRAFI}

Al Noman, Mohammad Abdulla, Sharmin, Tarana, Shoshi, Fatema Kabir, Anee, Kanij Fatima, Hossain, Md Belal, Islam, Md Nazrul, \& Khan, Md Shafiqul Islam. (2020). Occupational hazards and health care seeking behavior of fishermen. Asian Journal of Medical and Biological Research, 6(1), 38-43.

Anderson, Danielle E., Sivalingam, Velraj, Kang, Adrian Eng Zheng, Ananthanarayanan, Abhishek, Arumugam, Harsha, Jenkins, Timothy M., Hadjiat, Yacine, \& Eggers, Maren. (2020). Povidone-iodine demonstrates rapid in vitro virucidal activity against SARS-CoV-2, the virus causing COVID-19 disease. Infectious Diseases and Therapy, 9(3), 669-675.

Antipov, Evgeny A., \& Pokryshevskaya, Elena B. (2019). The effects of adverse drug reactions on patients' satisfaction: evidence from publicly available data on tamiflu (oseltamivir). International Journal of Medical Informatics, 125, 30-36.

Badan Nasional Penanggulangan Bencana (BNPB). (2020). Data Sebaran COVID-19 di Indonesia (Internet).

Barnes, Mark, \& Sax, Paul E. (2020). Challenges of "return to work" in an ongoing pandemic. New England Journal of Medicine, 383(8), 779-786.

Brooks, Samantha K., Webster, Rebecca K., Smith, Louise E., Woodland, Lisa, Wessely, Simon, Greenberg, Neil, \& Rubin, Gideon James. (2020). The psychological impact of quarantine and how to reduce it: rapid review of the evidence. The Lancet, 395(10227), 912-920.

Carr, Anitra C., \& Maggini, Silvia. (2017). Vitamin C and immune function. Nutrients, 9(11), 1211.

Casale, Manuele, Rinaldi, Vittorio, Sabatino, Lorenzo, Moffa, Antonio, \& Ciccozzi, Massimo. (2020). Could nasal irrigation and oral rinse reduce the risk for COVID19 infection? International Journal of Immunopathology and Pharmacology, 34, 2058738420941757.

Dalimartha, Setiawan, \& Adrian, Felix. (2013). Fakta Ilmiah Buah Sayur. Penebar PLUS+.

Damanik, Rani Kawati, \& Gulo, Adventy Riang Bevy. (2020). Pengaruh Metode Ppni Information System Dengan Kecepatan Perhitungan Kebutuhan Perawat. Jurnal Kesehatan, 11.

Durrani, Misbah, Inam ul Haq, Ume Kalsoom, \& Yousaf, Anum. (2020). Chest X-rays findings in COVID 19 patients at a University Teaching Hospital-A descriptive study. Pakistan Journal of Medical Sciences, 36(COVID19-S4), S22. 
Dwinantoaji, Hastoro, \& Sumarni, D. W. (2020). Human security, social stigma, and global health: The COVID-19 pandemic in Indonesia. Journal of the Medical Sciences (Berkala Ilmu Kedokteran), 52(3).

Dwiyanti, Widya. (2017). The Stage's of Sharing Knowledge among Students in Learning Environment: A Review of Literatur. International Journal of Education and Research, 5(8), 81-92.

Ehrlich, Haley, McKenney, Mark, \& Elkbuli, Adel. (2020). Protecting our healthcare workers during the COVID-19 pandemic. The American Journal of Emergency Medicine, 38(7), 1527-1528.

Fan, Peijin Esther Monica, Aloweni, Fazila, Lim, Shu Hui, Ang, Shin Yuh, Perera, Karen, Quek, Aik Huan, Quek, Hwee Koon Susan, \& Ayre, Tracy Carol. (2020). Needs and concerns of patients in isolation care units-learnings from COVID-19: A reflection. World Journal of Clinical Cases, 8(10), 1763.

Febriani, Yessi, Riasari, Hesti, Winingsih, Wiwin, Aulifa, Diah Lia, \& Permatasari, Ayu. (2018). The Potential Use of Red Ginger (Zingiber officinale Roscoe) Dregs as Analgesic. Indonesian Journal of Pharmaceutical Science and Technology, 1(1), 57-64.

Guo, Zhen Dong, Wang, Zhong Yi, Zhang, Shou Feng, Li, Xiao, Li, Lin, Li, Chao, Cui, Yan, Fu, Rui Bin, Dong, Yun Zhu, \& Chi, Xiang Yang. (2020). Aerosol and surface distribution of severe acute respiratory syndrome coronavirus 2 in hospital wards, Wuhan, China, 2020. Emerging Infectious Diseases, 26(7), 1586.

Hadaya, Joseph, Schumm, Max, \& Livingston, Edward H. (2020). Testing individuals for coronavirus disease 2019 (COVID-19). Jama, 323(19), 1981.

Hafeez, Abdul, Ahmad, Shmmon, Siddqui, Sameera Ali, Ahmad, Mumtaz, \& Mishra, Shruti. (2020). A review of COVID-19 (Coronavirus Disease-2019) diagnosis, treatments and prevention. EJMO, 4(2), 116-125.

Harapan, Harapan, Itoh, Naoya, Yufika, Amanda, Winardi, Wira, Keam, Synat, Te, Heyhpeng, Megawati, Dewi, Hayati, Zinatul, Wagner, Abram L., \& Mudatsir, Mudatsir. (2020). Coronavirus disease 2019 (COVID-19): A literature review. Journal of Infection and Public Health.

Huang, Yeen, \& Zhao, Ning. (2020). Generalized anxiety disorder, depressive symptoms and sleep quality during COVID-19 outbreak in China: a web-based cross-sectional survey. Psychiatry Research, 288, 112954.

Iddir, Mohammed, Brito, Alex, Dingeo, Giulia, Fernandez Del Campo, Sofia Sosa, Samouda, Hanen, La Frano, Michael R., \& Bohn, Torsten. (2020). Strengthening the immune system and reducing inflammation and oxidative stress through diet and nutrition: considerations during the COVID-19 crisis. Nutrients, 12(6), 1562. 
Indonesia, Lembaga Ilmu Pengetahuan, \& Indonesia, Reformasi Birokrasi Lembaga Ilmu Pengetahuan. (2012). LIPI. Retrieved from LIPI Website: http://www. lipi. go. id.

Kompas.com. (2020). Cerita Para Pasien Covid-19 yang Isolasi Mandiri, Tak Dipantau Petugas hingga Terpaksa Keluar Rumah. Retrieved from //makassar.kompas.com/read/2020/10/07/06120041/cerita-para-pasien-covid-19yang-isolasi-mandiri-tak-dipantau-petugas-hingga?page=all

Lee, Yonghyun, Min, Pokkee, Lee, Seonggu, \& Kim, Shin Woo. (2020). Prevalence and duration of acute loss of smell or taste in COVID-19 patients. Journal of Korean Medical Science, 35(18).

Mangalla, Lukas K., Simatupang, Minson, Samhuddin, Samhuddin, Kadir, Kadir, \& Kadir, Abd. (2020). Penerapan Inovasi Tirai Isolasi Mandiri Pasien Covid-19. Jurnal Pengabdian Masyarakat Ilmu Terapan (JPMIT), 2(2), 139-144.

Miyauchi, Masaatsu, \& Nakajima, Hideaki. (2016). Determining an effective UV radiation exposure time for vitamin D synthesis in the skin without risk to health: Simplified estimations from UV observations. Photochemistry and Photobiology, 92(6), 863-869.

Morey, Jennifer N., Boggero, Ian A., Scott, April B., \& Segerstrom, Suzanne C. (2015). Current directions in stress and human immune function. Current Opinion in Psychology, 5, 13-17.

Ooi, Eng Eong, \& Low, Jenny G. (2020). Asymptomatic SARS-CoV-2 infection. The Lancet Infectious Diseases, 20(9), 996-998.

Perhimpunan Dokter paru Indonesia (PDPI). (2020). PerhimpunanDokter Spesialis Kardiovaskular Indonesia (PERKI), Perhimpunan Dokter Spesialis Penyakit Dalam Indonesia (PAPDI), Perhimpunan Dokter Anestesiologi dan Terapi Intensif Indonesia (PERDATIN), Ikatan Dokter Anak Indonesia (IDAI). Pedoman Tatalaksana COVID-19.

Pusparini, Pusparini. (2020). Tes serologi dan polimerase chain reaction (PCR) untuk deteksi SARS-CoV-2/COVID-19. Jurnal Biomedika Dan Kesehatan, 3(2), 46-48.

Riyan, Arnold, Prijana, Prijana, \& Sukaesih, Sukaesih. (2015). Potensi Membaca Buku Teks (Studi Pada Mahasiswa Program Studi Ilmu Perpustakaan Fakultas Ilmu Komunikasi Universitas Padjadjaran Bandung). Jurnal Kajian Informasi \& Perpustakaan, 3(1), 81-88.

Samarghandian, Saeed, Farkhondeh, Tahereh, \& Samini, Fariborz. (2017). Honey and health: A review of recent clinical research. Pharmacognosy Research, 9(2), 121. 
Santosa, Santi Puspa Ariyani. (2020). (2020). Analisis Pengaruh Social Distancing Dalam Pencegahan Penyebaran Virus Corona Dengan Pelaksanaan Sholat Fardhu Berjamaah Di Masjid Al Ikhlas Desa Sukoharjo Kecamatan Margorejo Kabupaten Pati Jawa Tengah. Jurnal Syntax Idea, 2(5).

Saputri, Marliana Eka, \& Moordiningsih, Moordiningsih. (2016). Pembentukan konsep diri remaja pada keluarga jawa yang bergama islam. Jurnal Ilmiah Psikologi Terapan, 4(2), 261-268.

Sepúlveda-Loyola, W., Rodríguez-Sánchez, I., Pérez-Rodríguez, P., Ganz, F., Torralba, R., Oliveira, D. V, \& Rodríguez-Mañas, Leocadio. (2020). Impact of social isolation due to COVID-19 on health in older people: Mental and physical effects and recommendations. The Journal of Nutrition, Health \& Aging, 1-10.

Shirvani, Hossein. (2020). Exercise and COVID-19 as an Infectious Disease. Iranian Journal of Medical Sciences, 45(4), 311-312.

Siste, Kristiana, Hanafi, Enjeline, Lee Thung Sen, Hans Christian, Adrian, Levina Putri Siswidiani, Limawan, Albert Prabowo, Murtani, Belinda Julivia, \& Suwartono, Christiany. (2020). The Impact of Physical Distancing and Associated Factors Towards Internet Addiction Among Adults in Indonesia During COVID-19 Pandemic: A Nationwide Web-Based Study. Frontiers in Psychiatry, 11.

Stuart, Gail W., Keliat, Budi A., \& Pasaribu, Jesika. (2016). Prinsip dan praktik keperawatan kesehatan jiwa Stuart. Keliat BA, Editor, 1.

Van Gorkom, Gwendolyn N. Y., Klein Wolterink, Roel G. J., Van Elssen, Catharina H. M. J., Wieten, Lotte, Germeraad, Wilfred T. V, \& Bos, Gerard M. J. (2018). Influence of vitamin C on lymphocytes: an overview. Antioxidants, 7(3), 41.

Wang, Manli, Cao, Ruiyuan, Zhang, Leike, Yang, Xinglou, Liu, Jia, Xu, Mingyue, Shi, Zhengli, Hu, Zhihong, Zhong, Wu, \& Xiao, Gengfu. (2020). Remdesivir and chloroquine effectively inhibit the recently emerged novel coronavirus (2019$\mathrm{nCoV}$ ) in vitro. Cell Research, 30(3), 269-271.

Wong, Ho Yuen Frank, Lam, Hiu Yin Sonia, Fong, Ambrose Ho Tung, Leung, Siu Ting, Chin, Thomas Wing Yan, Lo, Christine Shing Yen, Lui, Macy Mei Sze, Lee, Jonan Chun Yin, Chiu, Keith Wan Hang, \& Chung, Tom Wai Hin. (2020). Frequency and distribution of chest radiographic findings in patients positive for COVID-19. Radiology, 296(2), E72-E78.

Wu, Peng, Hao, Xinxin, Lau, Eric H. Y., Wong, Jessica Y., Leung, Kathy S. M., Wu, Joseph T., Cowling, Benjamin J., \& Leung, Gabriel M. (2020). Real-time tentative assessment of the epidemiological characteristics of novel coronavirus infections in Wuhan, China, as at 22 January 2020. Eurosurveillance, 25(3), 2000044. 